\title{
Obraz Chin
}

\section{w eurazjatyckim \\ projekcie Borisa Pilniaka: od wyobrażonego}

do dokumentarnego*

Hui Zhang

ORCID: 0000-0002-3702-1839
*Artykuł powstał w ramach Shanghai

Pujiang Program [2019PJC093].

Boris Pilniak (1894-1938), pisarz będący świadkiem przechodzenia państwa rosyjskiego z okresu imperialnego w okres sowiecki, przy użyciu fragmentarycznego stylu spisał kronikę życia Rosjan w czasach społecznego i politycznego niepokoju. Choć w swych dziełach Pilniak tworzy prawdziwy kalejdoskop problemów, myśli i zjawisk, których autorzy starszego pokolenia nie mogli przewidzieć, dziedziczy on także mityczny obraz Azji i Chin dominujący w twórczości poetów i pisarzy srebrnego wieku. Wyróżnia go między innymi fakt, iż nie ogranicza się jedynie do „podróży wyobraźni”, ale cieszy się przywilejem doświadczenia Dalekiego Wschodu na własnej skórze, zetknięcia z codziennym życiem mieszkańców Chin i Japonii. Co więcej, kulturowo-polityczny projekt związany z mitem Chin znalazł w czasach Pilniaka nową odsłonę, którą znamy jako eurazjanizm wczesnych lat 20. ${ }^{1}$. Okoliczności te przyczyniły się do stworzenia przez Pilnia-

\footnotetext{
${ }^{1}$ Rosyjski eurazjanizm pierwotnie odnosił się do intelektualnego ruchu emigracyjnego w Rosji w latach 20. XX wieku, zwracającego uwagę na historyczną homogeniczność, kulturowe pokrewieństwo i relacje ekonomiczne między cywilizacjami Rosji i Azji - początkowo nomadycznymi. Dla różnych zwolenników eurazjanizmu koncepcja Eurazji zakładała różne centra, peryferia, struktury i granice, podczas gdy związek między Rosją, Eurazją i Chinami rodził jeszcze inne znaczenia i implikacje. Krótki wstęp na temat tego ruchu - zob. Mark Bassin, Sergey Glebov, Marlene Laruelle, „What Was Eurasianism and Who Made It?”, w Between Europe and Asia: The Origins, Theories, and Legacies of Russian Eurasianism, red. Mark Bassin, Sergey Glebov i Marlene Laruelle (Pittsburg: University of Pittsburg Press, 2015), 1-12.
} 
ka, w jego literackich podróżach do Chin, wyjątkowej perspektywy stanowiącej odzwierciedlenie obsesyjnych myśli na temat historii i powołania Rosji, które jednakże w ciągu literackiej kariery pisarza ulegały nieustannym przemianom wraz ze zmiennymi kolejami narodu rosyjskiego.

Koncepcja Chin wyrażona w prozie pisarza była kontynuacją palimpsestowego procesu wpisywania mitu chińskiego w rosyjskie środowisko kulturowe, co znaczy, że Chiny w dziełach Pilniaka napisanych przed 1920 rokiem figurują głównie jako wytwór jego wyobraźni poetyckiej. Ta fantastyczna wizja Chin opiera się na nieograniczonym użyciu licencji poetyckiej, generującej różnorodne symboliczne sensy dotyczące państwa chińskiego w powieści Nagi rok (Golyi god, 1922). Od roku 1922 Chiny w dziełach Pilniaka nabywają całkowicie nowych znaczeń. Dwa utwory, Sankt-Piter-Burkh (1922) oraz Bol'shoe serdtse (Wielkie serce, 1927), z jednej strony potwierdzają wiedzę pisarza na temat społeczeństwa i historii państwa chińskiego, z drugiej reprezentują wpływ, jaki na postrzeganie Chin miały ówczesne wydarzenia. Pisanie opowieści Sankt-Piter-Burkh zeszło się z rewolucją Xinhai, która wybuchła w październiku 1911 roku i która zakończyła imperialną erę chińskiej historii. Również Wielkie serce Pilniak tworzył w trakcie narodzin Ruchu $30 \mathrm{Maja}^{2}$, związanego $\mathrm{z}$ antyimperialistycznym buntem i demonstracją, do których doszło w Szanghaju w maju 1925 roku. Nacjonalistyczne i sprzeciwiające się imperialnej polityce nastroje, wywołane przez oba wydarzenia, wpłynęły na kompozycję dwóch dzieł Pilniaka. Jako reprezentant rządowy pisarz spędził lato 1926 roku w Chinach, by stworzyć bezpośrednią relację z życia w tym republikańskim państwie i założyć Chińsko-Rosyjskie Stowarzyszenie Literacko-Artystyczne. Zarówno nowo nabyta wiedza na temat państwa chińskiego, jak i osobisty kontakt z Chińczykami podważyły i zmieniły mityczną wizję kraju, dostarczając Pilniakowi materiału do bardziej realistycznego przedstawienia Chin w dziele Kitaiskii dnevnik (Dziennik chiński, 1927). Dziennik objawił radzieckim czytelnikom Chiny pogrążone w społecznym chaosie, co mogło przypomnieć im o ich własnym państwie z całkiem niedawnej przeszłości.

Jak się okazuje, wizja państwa chińskiego we wczesnych pracach Pilniaka miała niewiele wspólnego z nowoczesną rzeczywistością. Najbardziej imponującą odsłonę tej początkowej perspektywy dostrzec można w powieści Nagi rok (ukończonej w roku 1920). Pilniak wykorzystuje tam symboliczny obraz „China-town” („Kitai-gorod”) ${ }^{3}$ jako spajający element lirycznego „refrenu”, który stoi poza narracyjnymi ramami fragmentarycznych wydarzeń powieści, ale zawiera jej rdzeń i tym samym łączy ze sobą owe (otaczające go) wydarzenia ${ }^{4}$. Refren ten, który pojawia się

\footnotetext{
${ }^{2}$ W oryg. pojawia się błąd. Zamiast „May Thirteenth Movement” powinien być „May Thirtieth Movement” przyp. tłum.

${ }^{3}$ W rzeczywistości Kitaj-gorod to historyczna dzielnica Moskwy, obszar otoczony murem („Kitaigorodskaia krepostnaia stena”) wzniesionym w 1538 roku jako fortyfikacja i później zrównanym z ziemią. Kitaj-gorod funkcjonował w XVI wieku jako dzielnica arystokratyczna, później pełniąca funkcję handlowego i kulturalnego centrum Moskwy. Pochodzenie nazwy „Kitaj-gorod” jest wciąż kwestią dyskusyjną: jedno z powszechnych wyjaśnień odsyła do słowa „kita” oznaczającego „wiązanie słupów” (the binding of poles), co miało odzwierciedlać konstrukcję fortyfikacji. Zob. Aleksandr Prokhorov, red., Bol'shaia sovetskaia entsiklopediia (Moscow: Sov. entsiklopediia, 1973), vol. 12, 242.

${ }^{4}$ Gary Browning analizuje użycie przez Pilniaka tego konkretnego narzędzia, określając go mianem „narastającego refrenu" (accretive refrain). Zob. Gary Browning, Boris Pilniak: Scythian at a Typewriter (Ann Arbor: Ardis Publishers, 1985), 120-125. Robert Maguire podkreśla zamiłowanie Pilniaka do powtórzeń, które korzystają $\mathrm{z}$ artystycznego repertuaru incydentalnych zdarzeń, obrazów, motywów. Katalog obrazów Pilniaka, pod względem stylu zorganizowany w parataktyczną strukturę, często pełni alegoryczne funkcje. Zob. Robert Maguire, Red Virgin Soil: Soviet Literature in the 1920's (Evanston: Northwestern University Press, 2000), 118-124.
} 
najpierw we wczesnych partiach powieści, a potem pod koniec, przedstawia trzy „China-town” - Moskwy, Niżnego Nowogrodu i Orydinu - na wzór tryptyku, tj. w formie trzech paneli, niezależnych od siebie, ale paralelnych pod względem struktury. W każdym z tych paneli „chińska dzielnica” objawia się jako kolaż, na który składają się dowolnie połączone elementy odsyłające do różnych zmysłów. Zarówno przedmioty, jak ich właściwości - kształty, kolory, tekstury, zapachy itp. - ułożone są w taki sposób, aby zwiększyć ornamentacyjny i impresjonistyczny efekt opisu. Pomimo przestrzennego nieładu w dwóch pierwszych przedstawieniach Kitaj-gorodu można zaobserwować pewną sekwencję czasową: moskiewskie „China-town” ukazuje kontrast pomiędzy dniem a nocą, podczas gdy niżnonowogrodzkie - kontrast między jesienią a zimą. Każdemu elementowi tych temporalnych par odpowiadają określone wrażenia i tonacje:

W ciągu dnia Kitajgorod, za chińskim murem, kłębił się milionami ludzi i milionem istnień ludzkich w melonikach, w kapeluszach filcowych, w kożuchach - sam w meloniku, z teką obligacji, akcji, weksli, specyfikacji, obliczeń giełdowych - ikon, skór, manufaktury, rodzynek, złota, platyny, Martjanycza cały w meloniku, prawdziwa Europa. A nocą z kamiennych zaułków i tylnych podwórek znikały meloniki, następowało bezludzie i cisza, węszyły bezpańskie psy, martwym blaskiem świeciły wśród murów latarnie i tylko z ciągów handlowych i do ciągów, tam i z powrotem, przesuwali się ludzie, rzadcy jak psy - i w czapkach. I wówczas w tej pustyni z podwórek i podwóreczek wypełzały one - Chiny bez melonika, Niebiańskie Imperium, które leży gdzieś za stepami na wschodzie, za Wielkim Murem, i patrzy na świat skośnymi oczami, przypominającymi guziki rosyjskich żołnierskich szynelów. To jeden Kitajgorod ${ }^{6}$.

W Niżnym Nowogrodzie, na przedmieściu Kanawino, za Makarym, olbrzymim zadem rozsiadła się ta sama moskiewska Iljinka, w listopadzie - po wrześniowych milionach pudów, beczek, sztuk, arszynów i ćwierci towarów zamienionych na ruble, franki, marki, szterlingi, dolary, liry i inną walutę, po październikowej hulance, zza kurtyny rozlanego przez Wołgę wina, kawioru, „Wenecji”, „Europejskich”, „Tatarskich”, „Perskich”, „Chińskich” i litrów spematoizodów - w listopadzie, w Kanawinie, w śniegu, z pozamykanych sklepików, ze zrujnowanych budek, z pustki - patrzą żołnierskimi guzikami zamiast oczu tamte: nocne, moskiewskie, Wielkim Murem zamknięte Chiny. Kitajgorod. Milczenie. Nie do odgadnięcia. Bez melonika. Żołnierskie guziki zamiast oczu?

\footnotetext{
${ }^{5}$ Współcześnie słowo „Kitaj” w języku rosyjskim oznacza „Chiny”. Stąd pojawiające się w oryginale artykułu „China-town” jest zabawą, dosłownym tłumaczeniem „Kitaj-gorod”- przyp. tłum.

${ }^{6}$ Boris Pilnyak, Nagi rok, tłum. Janina Dziarnowska (Warszawa: Państwowy Instytut Wydawniczy, 1987), 32. Oryg: „Днем Китай-Город, за китайской стеной, ворочался миллионом людей и миллионом человеческих жизней - в котелках, в фетровых шляпах и зипунах,- сам в котелке и с портфелем облигаций, акций, векселей, накладных, биржи,- икон, кож, мануфактур, изюмов, золота, платины, Мартьяныча,- весь в котелке, совсем Европа.- А ночью из каменных закоулков и с подворий исчезали котелки, приходили безлюдье и безмолвье, рыскали собаки, и мертво горели фонари среди камней, и лишь из Зарядья и в Зарядье шли люди, редкие, как собаки, и в картузах. И тогда в этой пустыне из подворий и подворотен выползал тот: Китай без котелка, Небесная Империя, что лежит где-то за степями на востоке, за Великой Каменной Стеной, и смотрит на мир раскосыми глазами, похожими на пуговицы русских солдатских шинелей.- Это один Китай-Город”. Boris Pilnyak, Sobranie Sochinenii (Moscow: Gos. izd-vo., 1929), vol. 1, 55.

7 Pilnyak, Nagi rok, 32-33. Oryg: „В Нижнем-Новгороде, в Канавине, за Макарьем, где по Макарью величайшей задницей та же рассаживалась московская дневная Ильинка, в ноябре, после сентябрьских миллионов пудов, бочек, штук, аршин и четвертей товаров, смененных на рубли, франки, марки, стерлинги, доллары, лиры и прочие, - после октябрьского разгулья, под занавес разлившегося Волгой вин, икор, «Венеции», «европейских», «татарских», «персицких», «китайских» и литрами сперматозоидов,- в ноябре в Канавине, в снегу, из заколоченных рядов, из забитых палаток, из безлюдья - смотрит солдатскими пуговицами вместо глаз - тот: ночной московский и за Великой Каменной Стеной сокрытый: Китай. Безмолвие. Неразгадка. Без котелка. Солдатские пуговицы - вместо глаз”. Pilnyak, Sobranie Sochinenii, vol. 1, 55.
} 
Moskiewski Kitaj-gorod za dnia jest miejscem handlu: skojarzony z kupcami noszącymi „meloniki” i z wszelkiego rodzaju towarami, które kupcy ze sobą przywożą, zmienia się w „prawdziwą Europę”. W podobny sposób przedstawia się niżnonowogrodzkie „China-town” we wrześniu i październiku. Ono także stanowi miejsce spotkań przedsiębiorców, z takim wyjątkiem, że tu „europejskie” marki zestawione są z azjatyckimi - „tatarskimi”, „perskimi”, „chińskimi”. Odpowiednio obie dzielnice, gdy przychodzi noc bądź gdy nadchodzi zima, pustoszeją i cichną. Istotne jest nie tylko to, że zmienia się radykalnie ich wygląd podług cyklicznego wzorca, ale także to, że zmienia się ich forma egzystencji zarówno w wymiarze geograficznym, jak i metafizycznym. „Chiński mur” dnia, który odnosi się do średniowiecznych fortyfikacji otacząjących moskiewską dzielnicę, nocą zostaje zastąpiony „Wielkim Murem”, a sam Kitaj-gorod, handlowe centrum miasta, przenosi się poza granicę Rosji, do „Niebiańskiego Imperium”, skąd biegnie wpatrzone spojrzenie, nie tyle oczu, ile "guzików rosyjskich żołnierskich szynelów”. Podobny obraz pojawia się w „chińskiej dzielnicy” Ordyninu, gdzie ustała wszelka działalność ludzka, ustępując miejsca siłom natury. W przeciwieństwie do dwóch pierwszych „China-town”, dzielnica Ordyninu nie odznacza się płynnością czasu: jest opuszczonym i opustoszałym miejscem, gdzie w marcu wciąż królują śnieg i wiatr, a fabryki i sklepy pokrywa rdza. W tym miejscu „guziki” spoglądają z odlewni, a po „melonikach” nie ma ani śladu.

Każde z wymienionych „chińskich dzielnic” można czytać jako alegorię rosyjskiej tożsamości. Opis moskiewskiego Kitaj-gorodu rysuje wyraźną opozycję między dniem a nocą, która kojarzone odpowiednio z Europą i Azją. Zmieniająca się w tej codziennej scenerii tożsamość dzielnicy odzwierciedla historyczną tożsamość Rosji, która wahała się między europejską a azjatycką. Przemiana Kitaj-gorodu w samo „Kitaj” (Chiny) to zabieg alegoryczny, w którym odsłania się proces stawania się „Azjatą”, ujawnia się azjatycka strona rosyjskiego ducha. Znaczenie „Chin” z tego fragmentu zostaje naświetlone w innej powieści Pilniaka, Maszyny i wilki (Mashiny i volki, 1925), gdzie „China-town" także się pojawia. W ostatnim rozdziale tego dzieła-montażu, ukończonego cztery lata po Nagim roku, Pilniak umieścił opis moskiewskiej „chińskiej dzielnicy” z wcześniejszej powieści. W tym autocytacie dostrzec można kilka drobnych zmian, na przykład: „I wtedy, w rojowisko pustyni, podwórek i bram wypełzał prawdziwy Kitaj-gród (podlinnyi Kitai-gorod)"9. Ta forma adaptacji potwierdza tezę, iż Pilniak pragnie, by Kitaj-gorod stał się symbolicznym nośnikiem azjatyckiego dziedzictwa Rosji, które w świetle dnia pozostaje ukryte i ujawnia się dopiero po zmroku.

Czy na temat owego azjatyckiego dziedzictwa, tych nieodłącznych „Chin” w ontogenezie Rosji, Pilniak wyraża swoją opinię czy ocenę? W przedstawieniu „dzielnicy chińskiej” Ordyninu Chiny zdają się ucieleśniać upartą i nieprzyjazną siłę natury, która unieruchamia życie i pracę, zniechęca ludzi do podejmowania działań i hamuje postęp. Jednym słowem, wizję tę można łączyć z osławionym kitaizmem, który zapewne przyszedł Pilniakowi do głowy, gdy ten obserwował zacofane i statyczne życie Rosjan na prowincji: „, Z zakopconych hal, z frezarek i tokarek, z młotów i dźwigów, $\mathrm{z}$ wielkiego pieca, $\mathrm{z}$ walcowni i pordzewiałych blach patrzą - Chiny, uśmiechają się drwiąco (bo jak się mogą uśmiechać!) żołnierskie guziki" ${ }^{10}$. Ta negatywna odsłona państwa chińskiego prowadzi

${ }^{8}$ Pilnyak, Sobranie Sochinenii, vol. 1, 56.

${ }_{9}^{9}$ Boris Pilniak, Maszyny i wilki, tłum. Janina Dziarnowska (Warszawa: Czytelnik, 1984), 322. Oryg. Mashiny i volki (Munich: W. Fink, 1925), podkr. - H.Z.

${ }^{10}$ Pilniak, Nagi rok, 33. Oryg. Sobranie Sochinenii, 56. Kitaizm to pogląd, według którego Chiny stanowiły symbol inercji, stagnacji i duchowej jałowości w kontekście rozwoju społecznego i charakteru narodu. Zyskał popularność w rosyjskim dyskursie akademickim i intelektualnym pod koniec XIX wieku dzięki pismom Dostojewskiego, Hercena, Sołowjowa itd. 
do drugiej opozycji w myśli autora na temat charakteru Rosji - opozycji pomiędzy naturalnym chaosem ucieleśnionym w ponurym, wiejskim krajobrazie a sztucznym porządkiem reprezentowanym przez nowo stawiane fabryki i nowoczesną technologię. Choć ordynińskie "China-town" pojawia się w pierwszych fragmentach Nagiego roku jako pozbawione życia, odradza się na nowo dzięki robotnikom i inżynierom wskrzeszającym fabrykę (zavod - samovozrodilsja). Podobna opozycja między zastojem a mobilnością, między destrukcją a konstruowaniem zawarta jest w szkicu dotyczącym moskiewskiej „dzielnicy chińskiej” w Maszynach i wilkach Pilniaka:

Przez cztery lata, co rok od marca do maja wody wiosenne podmywały fundamenty Kitaj-grodu a od maja do marca rozwalał osinową pałą Kitaj-gród - moskiewską Iljinkę, która nie odpoczywała nawet nocą w ciągu owocowych targów w lecie - każdy, kto mógł, z całych sił, świadomą wolą ludu i przez bezmyślny wandalizm - rozbierano drzewo na opał, szyldy - na pokrycie dachów, szyby, aby brzęczały radośnie rzucone o kamień, cegły na piecyki do ogrzewania mieszkań, na remont domów, na pomnik poległych w Październiku ${ }^{11}$.

Choć w portretowaniu Kitaj-gorodu, zarówno w Nagim roku, jak i w Maszynach i wilkach, opozycja zdaje się odgrywać główną rolę, pojawia się w nim także przebłysk harmonii i jedności. W Nagim roku „China-town” w Niżnym Nowogrodzie gromadzi towary z Europy i Azji, natomiast w Maszynach i wilkach moskiewska „dzielnica chińska” jest miejscem, w którym spotykają się „perscy”, „tatarscy”, „kaukascy” „uralscy” i „ukraińscy” przedsiębiorcy sprowadzający towary z każdego zakątka Rosji, dzięki czemu przekształcają ją w centrum handlowe, które przypomina XIX-wieczny rynek wymiany. Te dwa miejsca handlowe przywołują nie eurocentryczne, ale eurazjatyckie wrażenia, tworząc mikrokosmos transkontynentalnej Rosji. W terminologii Pilniaka „Chiny” rodzą się ponownie na „rynku eurazjatyckim”, ale nie jako państwo odizolowane i wyludnione, strzeżone przez Wielki Mur, ale jako państwo wskrzeszone, którego bramy stoją otworem dla wszystkich mieszkańców Eurazji. Te nowe „Chiny” korespondują nie tyle z przeszłością Rosji, co z jej wieloetniczną i wielokulturową przyszłością, którą mają stworzyć bolszewicy:

...i oto inna wola wskrzesiła znów Kitaj-gród - inni ludzie. [...] Pociągami, parostatkami - tysiące pudów, beczek, sztuk, ćwierci, arszynów - zaczęły napływać towary - z puszcz, z mokradeł, z fabryk, gór, z Morza Kaspijskiego, Białego, z Czusowej, Peczory i Obi - od łuczywa, od lampek naftowych, z turbinami i wprost od słońca i zorzy polarnej - na radość i smutek, na śmierć i narodzenie - aby żyć - jak żyła Ruś przez stulecia. - Persowie, Tatarzy, Kaukazczycy, Uralczycy, Ukraińcy - tysiące - a wraz z nimi meloniki, okrągłe okulary w rogowej oprawie, fajki - Azja z Europą - Azeur - Eurazja - został otwarty wszechrosyjski magazyn uniwersalny - GUM¹2.

\footnotetext{
${ }^{11}$ Pilniak, Maszyny i wilki, 322-323. Oryg.: „с марта по май стужные воды размывали в Китае-городе содеянное - и с мая по март рушили Китай-город осиновым колом - московскую Ильинку без ночей в три плодоносных месяца за летом - рушили кто как мог, все всеми силами, волею народной и народным озорством; - дерево на топливо, вывески - на крыши, стекла - на звон от камней, кирпичи - на камни, на печурки по бездровью, на ремонт домов, на памятник октябрьского восстания; [...]”. Pilnyak, Mashiny i volki, 177.

${ }^{12}$ Pilniak, Maszyny i wilki. Oryg.: „...и вот иная воля возродила вновь Китай - иные люди. [...] На поездах, пароходами, - тысячи пудов, бочек, штук, четвертей, аршин - потянулись товары - из лесов, с болот, заводов, гор, с Каспия, Белого моря, с Чусовой, Печоры и Оби, - от лучин, от керосиновых лампочек, от турбинных, просто от солнца и от северного сияния - на горе и радость, на смерть и рождение, - чтобы жить, как жила Русь столетьем. - Персы, татары, кавказцы, уральцы, украинцы тысячи - с ними котелки, круглые очки в оправе, трубки, - Азия с Европой, - Азевр - Евразия открывался всероссийский Гум".
} 
Choć „Kitaj” obecne w Nagim roku odnosi się do Chin mitycznych, które ostatecznie skierowane zostaną w stronę zakodowanej w tekście Rosji, w późniejszych dziełach Pilniaka wątki chińskie związane są z rzeczywistym obrazem Chin, przedstawiają zarówno ich imperialną historię, jak i republikańską teraźniejszość. W dziele Sankt-Piter-Burkh Pilniak przygląda się Chinom czasów starożytnych i nowoczesnych, które zestawia odpowiednio z Rosją Piotra Wielkiego i Rosją mu współczesną. Posiadający nieskończoną linię fabularną utwór Sankt-Piter-Burkh składa się z migawek zaczerpniętych z różnych etapów historii Chin i Rosji, a także z niepełnych portretów kilku postaci pochodzących z różnych epok i państw, w tym żołnierza Chińskiej Armii Czerwonej, żołnierza Rosyjskiej Armii Czerwonej, Rosjanina-inżyniera, żołnierza rosyjskiej Białej Armii, Piotra Wielkiego i cesarza Kangxi. Jak sama nazwa wskazuje, Sankt-Piter-Burkh stanowi uzupełnienie kanonu tekstów o micie petersburskim, tradycji literackiej ustanowionej i wzbogacanej przez takich XIX-wiecznych mistrzów jak Puszkin, Gogol, Dostojewski itd. Zarówno w stylu, jak i w sposobie obrazowania Pilniaka objawia się silny wpływ Andrieja Biełego (1880-1934) i Dmitrija Mereżkowskiego (1865-1941), którzy także mieli swój udział w tworzeniu mitu petersburskiego ${ }^{13}$. Wkład Pilniaka $\mathrm{w}$ tradycję literacką zasadza się na tym, że przybliżył mit petersburski bliżej sowieckiego kontekstu społecznego, a także związał go $z$ historyczną narracją innego narodu. Taka rewizja mitu rzuciła nowe światło na jego znaczenie. Sankt-Piter-Burkh od Petersburga Biełego odróżnia to, że Pilniak w swojej koncepcji paralelnych historii nie koncentruje się już na „internalizacji Azji”, procesie wynikającym z obsesji na punkcie dawnej tożsamości rosyjskiej, ale wynosi „problem petersburski” poza ramy historyczne Rosji, na poziom bardziej ogólnoludzki, który staje się przyczynkiem do stworzenia uniwersalistycznej postawy inspirowanej anarchizmem.

Sankt-Piter-Burkh rozpoczyna się od metafory na temat czasu i historii, która powraca w dalszej części opowieści jako stały motyw:

Stulecia statecznie układają się w stosy jak talie kart. Talie stuleci inkrustowane są latami, aby lata tasować w wieki - w chińskich kartach. „Żaden sprzedawca bożków nie kłania się im, bo wie, z czego są zrobione”. Jak więc mają się kłaniać stulecia? Powinny się kłaniać samym sobie? Wiedzą, z czego powstały: nic dziwnego, że style lat można uporządkować jak kolory kart.

$[\ldots]$

Stulecia układają się w równomierne stosy jak talie kart. Który wróżbita z Kołomnej w Petersburgu potrafi rzucić karty tak, żeby historia mogła się powtórzyć, żeby lata powtórzyły karty stuleci i ułożyły się dokładnie tak samo po raz drugi?!14

\footnotetext{
${ }^{13} \mathrm{Na}$ temat petersburskiego lejtmotywu oraz wpływu Bełego i Mereżkowskiego na Pilniaka zob.: Nirman Moraniak-Bamburian, „B. A. Pilnyak i «Peterburgskii tekst»”, w B.A. Pilnyak. Issledovanija i materialy, mezhvuzovskii sbornik nauzhnykh trudov 1, red. Aleksandr Auer (Kolomna: Izd-vo. KGPI. 2001), 36-46; M.I. Liubomova, „O Peterburgskikh povestiakh Borisa Pilnyaka”, w Boris Pilnyak, Opyt sevodniashnevo prochteniia (Moscow: Nasledie, 1995), 55-62.

${ }^{14}$ Oryg.: „Столетия ложатся степенно колодами. Столетий колоды годы инкрустируют, чтоб тасовать годы векам - китайскими картами. - «Ни один продавец идолов не поклоняется богам, он знает, из чего они сделаны.» - Как же столетьям склоняться - перед столетьями? - они знают, из чего они слиты: не даром по мастям подбираются стили лет... [...] Столетия ложатся степенно, - колодами; - какая гадалка с Коломны в Санкт-Питер-Бурге китает картами так, что история повторяется, - что столетий колоды - годы повторяют раз, и два?!”. Boris Pilnyak, Sankt-Piter-Burkh (Letchworth: Prideaux Press, 1979), 5. Por. tłum. ang.: Boris Pilnyak, The Tale of the Unextinguished Moon and Other Stories, tłum. Beatrice Scott (New York: Washington Square Press, 1967), 99-100.
} 
Wewnątrz tej metafory kryje się nietzscheańska myśl: Historia jest wiecznym powrotem. Odnawia się sama, zmieniając sekwencję i układ istniejących wcześniej elementów, których symbolem są , "hińskie karty”, przypadkowo przetasowane w nowe porządki. Ani istota historii, ani mechanizm jej działania nie zmieniają się: historia nie jest odbiciem z góry założonego planu, ale raczej samowolną improwizacją. Nie jest, innymi słowy, zarządzana wolą bogów, którzy są niczym więcej jak bożkami stworzonymi przez ludzi i dla ludzi. Nie określa jej także wola pojedynczego człowieka, gdyż ludzkie przedsięwzięcia również determinowane są przez przypadek. Takie nieteologiczne spojrzenie na historię wiąże się nie tylko z obaleniem kosmopolitycznego ideału postępu, który leży w centrum pozytywistycznej moralności, ale też z zaprzeczeniem eschatologicznej czy mesjanistycznej wiary podzielanej przez wielu myślicieli srebrnego wieku, i czyni kwestie, takie jak „przeznaczenie Rosji” bądź „predestynowana misja Rosji”, bezzasadnymi.

Historia widziana oczami Pilniaka powtarza się wiele razy. W dziele Sankt-Piter-Burkh Rosja Piotra Wielkiego jest postrzegana jako powtórzenie Chin Qin Shi Huanga, których historia także, sama w sobie, jest zbudowana na serii repetycji. Pisarz wspomina o kilku historycznych wydarzeniach Cesarstwa Chińskiego, z których każde, na swój sposób, odpowiada wydarzeniom $\mathrm{z}$ historii Rosji. Przeanalizujmy te wątki zgodnie z ich chronologią. Najpierw pojawia się Qin Shi Huang, pierwszy cesarz Chin, założyciel dynastii Qin (221-207 p.n.e.), którego pisarz porównuje z Piotrem Wielkim. W opisie Pilniaka Qin Shi Huang „odciął Państwo Środka od świata Wielkim Murem Chińskim” oraz „zniósł wszystkie stopnie i insygnia” ${ }^{15}$. Czyny te ustawiałyby cesarza w opozycji do Piotra Wielkiego, który toruje Rosji drogę do Europy, a w społeczno-polityczne życie obywateli wprowadza tabele rang. Pilniak podkreśla jednak podobieństwo obu postaci: zarówno cesarz, jak i car zdobyli władzę absolutną nad narodem, a dzięki arbitralnym działaniom przekształcili model funkcjonowania swoich państw. Despotyzm Qin Shi Huanga zadał „śmiertelny cios feudalizmowi” ${ }^{16}$, podczas gdy autokracja Piotra I rozpoczęła europeizację Rosji. Pilniak sugeruje, że zarówno osobowość Piotra I, jak i jego sposób rządzenia odzwierciedlają dziedzictwo absolutyzmu i tyranii płynących w jego żyłach. Jak pisze autor, Piotr I pozostał carem tylko dlatego, że „nie żył wystarczająco długo, aby zostać Wielkim Chanem”"

Drugi wątek, o którym wspomina Pilniak w dziele Sankt-Piter-Burkh, poświęcony jest cesarzowi Yongle z dynastii Ming (1368-1644):

„Yongle (Jun-Lo), trzeci cesarz z dynastii Ming, przechodził tędy, gdy zmierzał na wojnę z Mongołami, zwolennikami dynastii Yuan, wygnanymi z Chin przez jego ojca, Hongwu": [słowa - H.Z.] wyryte na blokach białego marmuru ${ }^{18}$.

\footnotetext{
${ }^{15}$ Pilnyak, The Tale of the Unextinguished Moon: And Other Stories, 100. Qin Shi Huang zadekretował liczne reformy społeczne i administracyjne, w tym obalenie panów feudalnych na terytorium cesarstwa, ale nie wyeliminował całego systemu arystokratycznego. Zarządził także budowę Wielkiego Muru, aby chronić swoje imperium przed najazdami wrogich, koczowniczych ludów.

${ }^{16}$ Pilnyak. Królowie feudalni byli de facto władcami wielu państw feudalnych na Nizinie Chińskiej w Okresie Walczących Królestw (475-221 p.n.e). Qin Shi Huanga zniósł tytuł feudała, wyprowadzając tym samym Chiny z epoki państw feudalnych w czasy cesarskie ze scentralizowaną władzą.

${ }^{17}$ Pilnyak.

${ }^{18}$ Oryg.: „Третий император династии Да-Мин, Юн-Ло, прошол здесь, отправляясь на войну с монголами приверженцами династии Юан, изгнанными из Китая его отцом Хун-Ву, - она высечена на глыбах белого мрамора [...]". Pilnyak, Sankt-Piter-Burkh, 5. Por. tłum. ang.: Pilnyak, The Tale of the Unextinguished Moon and Other Stories, 99.
} 
Napis na marmurowej tablicy, która znajduje się w pobliżu Dushikou, miasta-twierdzy pod Wielkim Murem, odnosi się do jednej z pięciu kampanii wojskowych prowadzonych przeciwko Mongołom między 1413 a 1424 rokiem przez Zhu Di (cesarza Yongle), trzeciego cesarza z dynastii Ming. Mongolscy władcy Chin z dynastii Yuan (1271-1368) zostali pokonani przez Zhu Yuanzhanga (cesarza Hongwu), pierwszego cesarza dynastii Ming i ojca Zhu Di. Nieustannie jednak, zarówno wschodnie, jak i zachodnie plemiona mongolskie, stanowiły zagrożenie dla społecznej i politycznej stabilności północnej granicy Chin. Kampanie Zhu Di, które miały na celu wyeliminować zagrożenie mongolskie, częściowo zbiegły się z buntem Moskwy przeciwko jarzmowi tatarskiemu, które utrzymywało się do roku 1480. Pilniak zwraca uwagę na to konkretne wydarzenie, aby umieścić Chiny w łączącym je z Rosją historycznym kontekście, który zasadza się na stosunkach z Mongołami. Jest to interesujące tym bardziej, gdy weźmie się pod uwagę skłonność do łączenia Chin i Mongolii w jedno, która zakorzeniła się w myśli Władimira Sołowjowa (1853-1900) dotyczącej panmongolizmu i „chińskiego niebezpieczeństwa”. Od tamtej pory owa myśl krążyła wśród rosyjskich elit kulturowych, stanowiąc pożywkę dla wyobrażeń na temat „żółtego zagrożenia” i tworząc koncepcję azjatyckiej spuścizny płynącej w rosyjskiej krwi ${ }^{19}$. Bliższe spojrzenie na historię w prozie Pilniaka uświadamia czytelników, że „Wschód” jest tak naprawdę mentalnym konstruktem i obsesją pozbawioną semantycznej spójności. Zrozumiawszy to, czytelnik może spojrzeć na związek rosyjskiej i chińskiej historii $\mathrm{z}$ nowej perspektywy.

Trzecie historyczne wydarzenie w dziele Sankt-Piter-Burkh także wiąże się z obroną Cesarstwa Chińskiego przed mongolską inwazją:

I w to samo miejsce, trzynastego dnia drugiego księżyca, w tysiąc sześćset dziewięćdziesiątym szóstym, według chronologii kalendarza europejskiego, poszedł cesarz Kangxi, by zmorzyć głodem konie i żołnierzy w Szamo. Shamo znaczy to samo, co Gobi: Shamo to Gobi, pustynia ${ }^{20}$.

Zdania te odnoszą się do kampanii cesarza Kangxi z dynastii Qing (1644-1912) przeciwko Chanatowi Dżungarskiemu. Kangxi, współczesny Piotrowi Wielkiemu, zaaranżował rozstrzygającą bitwę o Jao Modo (Battle of Jao Modo), która doprowadziła do klęski Dżungarów. Bitwa stoczyła się w maju 1696 roku blisko miasta Dushikou, którędy Zhu Di przeprowadzał swoją antymongolską kampanię w 1424 roku. Punktem łączącym te trzy zdarzenia jest to, że wszystkie prezentują wpływ indywidualnej siły i decyzji na proces historyczny. Podczas gdy

\footnotetext{
${ }^{19}$ „Żółte zagrożenie” czy też „żółte niebezpieczeństwo” to pojęcie szeroko rozpowszechnione w kulturowym i politycznym dyskursie Europy od połowy XIX wieku do początków XX, którego źródłem jest niepokój intelektualistów i polityków związany z japońskim programem modernizacyjnym rozpoczętym po Restauracji Meiji (1868) i masowymi falami imigracji chińskich robotników do Europy i Ameryki. Z jednej strony „żółte zagrożenie" jako ideologiczny konstrukt było nierozerwalnie związane z siecią układów (network), jaką od lat 70. XIX wieku tworzą główne mocarstwa świata. Z drugiej strony, obraz „hord ze Wschodu” wyrósł także na irracjonalnym i psychotycznym niepokoju związanym z historyczną inwazją Hunów Attyli na Europę w VI wieku i z okresem Złotej Ordy w Rosji (XIII-XV). Pojęcie panmongolizmu pojawia się na przykład w pismach Sołowjowa, który traktuje je jako odpowiedź na japońskie powstanie w latach 90 . XIX wieku. W celu zgłębienia historii „żółtego zagrożenia” zob. Sabine Doran, The Culture of Yellow or the Visual Politics of Late Modernity (New York: Bloomsbury, 2013), 121-157.

${ }^{20}$ Oryg.: „И там же в тринадцатый день второй луны, в тысяча шестьсот девяносто шестом году, по европейскому летосчислению, прошол Император Конси, чтоб уморить голодом в Шамо и лошадей и солдат. Шамо значит тоже что Гоби: Шамо - есть Гоби, пустыня". Pilnyak, Sankt-Piter-Burkh, 5. Por. ang. tłum.: Pilnyak, The Tale of the Unextinguished Moon: And Other Stories, 99.
} 
autokracja Qin Shi Huanga całkowicie zmieniła kulturową i społeczną strukturę starożytnych Chin, militarne dokonania Yongla i Kangxi miały ogromny wpływ na geopolityczny status północnej granicy państwa. Pilniak konstruuje swoją historię w taki sposób, aby zbudować paralelę między Piotrem Wielkim a cesarzami Chin. Tak jak Qin Shi Huang jest pierwszym władcą dynastii Qin i pierwszym cesarzem na Nizinie Chińskiej, tak Piotr Wielki określany jest jako „pierwszy Piotr z dynastii Romanowów i pierwszy cesarz Równiny Rosyjskiej”21.

Sportretowany przez Pilniaka Piotr Wielki, podobnie jak Qin Shi Huang, miał obsesję na punkcie władzy i to ona doprowadziła go do szaleństwa. Tak jak cesarze Chin dążył do uporządkowania podległego mu terytorium zgodnie z własną wolą, czego rezultatem było powstanie Petersburga - wytworu kaprysu jednego człowieka, iluzji, która za dnia jawi się jako miraż biegnących prosto ulic, a nocą jako lodowata mgła. Nawiasem mówiąc, taki obraz Petersburga w prozie Pilniaka wyraźnie potwierdza wpływ Biełego na jego twórczość. Pilniak, podobnie do Biełego, postrzega Petersburg jako obcą inkrustację rosyjskiej ziemi, którą wymusił Piotr I:

Pozostaje Petersburgowi przeskoczyć z prostoliniowej ulicy w mgłę metafizyki, w unoszące się nad bagnami opary. Fiński dzień obiecał pozostać taki do wieczora i wraz z nadejściem mglistej nocy zatrzeć proste linie ulicy, zachmurzyć je mgłą ${ }^{22}$.

W opowieści Sankt-Piter-Burkh Petersburg Piotra Wielkiego jest zestawiony z Petersburgiem okresu rewolucji. Wydarzenia z przeszłości i teraźniejszości przeplatają się ze sobą, a między nimi brak jest naturalnych przejść. W Petersburgu z chwili obecnej występuje postać o imieniu Ivan Ivanovich Ivanov - bolszewik i profesor. Dowiadujemy się, że Ivana dręczą wyrzuty sumienia, ponieważ wysłał swojego brata, Petra, na śmierć. Petr Ivanovich Ivanov, officer Białej Armii, nie ginie, ale emigruje do Pekinu. Ivan znajduje się w samym centrum rekonstruowanego w opowieści mitu petersburskiego, łącząc przeszłość z teraźniejszością. Bohater z jednej strony przypomina Piotra Wielkiego, powtarzając jego grzech: car wysłał swojego syna na inkwizycję, czym pośrednio przyczynił się do jego śmierci, Ivan natomiast prześladował i wypędził własnego brata. Przynależność do rosyjskiej inteligencji także ma łączyć bohatera z Piotrem I, ponieważ, według Pilniaka, to właśnie car jest pierwszym „inteligentem” Rosji²3.

Żyjąc w ciemności, jak „karaluch w szczelinie”24, Ivan marnieje powoli i w samotności, jak jego miasto. Powiedziane jest, że „boi się przestrzeni”25, co przybliża go do równie samo-wyizolowanego bohatera Petersburga Biełego - Apollona Ableukhova. Jednym słowem, Ivan

\footnotetext{
${ }^{21}$ Oryg: „Первый Петр в династии Романовых и первый император Российской Равнины”. Pilnyak, Sankt-PiterBurkh, 6.

${ }^{22}$ Oryg: „Питербургу остаться сорваться с прямолинейной - проспекта - в туман метафизик, в болотную гарь. Тот же финляндский денек обещал быть к ночи - туманною ночью, уничтожить прямолинейность проспектов, затуманить туманом". Pilnyak, Sankt-Piter-Burkh, 13. Por. ang. tłum.: Pilnyak, The Tale of the Unextinguished Moon: And Other Stories, 107.

${ }^{23}$ W eseju Zakaz Nash Pilniak pisze: „Piotr oderwał Rosję od Rosji. Piotr powiesił się za ogon na Europie Iwanow-Razumnik mylił się, szukając początków rodu rosyjskiej inteligencji od Radiszczowa - to Piotr był pierwszym inteligentem”. Oryg.: „Петр оторвал Россию от России. Петр повесил себя за хвост на Европу Разумник Васильич Иванов был неправ, начав род русской интеллигенции с Радищева, - Петр первым был интеллигентом". Boris Pilnyak, Stat’i 1922-1929 (Moscow: Sovetskii pisatel', 1991), 254.

${ }^{24}$ Pilnyak, Sankt-Piter-Burkh, 16.

${ }^{25}$ Pilnyak.
} 
cierpi na "gorączkę piotrową” bądź na „petersburgizm” (Petrovshchina, Likhoradka, Sankt-piterburgovshchina) ${ }^{26}$, obcą chorobę, która, jak obrazuje tytuł opowieści Pilniaka, odseparowała pokolenia rosyjskiej inteligencji od reszty narodu i podzieliła ich tożsamość.

Okazuje się więc, że Ivan, choć rewolucjonista, nie może pojąć prawdziwego znaczenia rewolucji, którą Pilniak postrzega jako „bunt ludu” rozpalony w duchu Pugaczowa i Razina. Istotę rewolucji rosyjskiej w rozumieniu Pilniaka podsumowują następujące słowa inżyniera Andrieja Liudogovskiego, przyjaciela Ivana:

Uważam, że w Rosji istnieje głęboko zakorzeniona kondycja narodowa, konieczny ruch, który nie ma nic wspólnego z europejskim syndykalizmem. W Rosji toczy się anarchistyczna rewolta w imię bezrządu, przeciwko jakimkolwiek rządom. Myślę, że Rosja musiała doświadczyć, i doświadcza, piotrowej gorączki, petersburgizmu, gorączki idei, teorii, matematycznego katolicyzmu. Stawiam na bolszewizm i razinizm, odrzucam komunizm ${ }^{27}$.

Jeśli siłą napędzającą „anarchistyczną rewoltę” jest wola narodu, to nowa Rosja, która się z tej woli narodzi, powinna być postrzegana jako całkowite przeciwieństwo Petersburga będącego wytworem woli jednego człowieka. W tym miejscu ponownie krzyżują się ścieżki Rosji i Chin, ponieważ w czasie, gdy Pilniak pisał swoją historię, Chiny ogarnęła rewolucja, a dynastia Qing, ostatnia dynastia cesarska, ujrzała swój koniec. „Bożkowie”, których zwykli ludzie uznawali za „Bogów”, abdykowali z historii Rosji i Chin mniej więcej w tym samym czasie.

Z perspektywy inżyniera obietnica rewolucji - postrzegana jako spontaniczny wybuch narodowej energii - powinna uzasadniać aktualne niedole narodu rosyjskiego; jak bohater sam wskazuje w odpowiedzi na cierpienie Iwana:

„Pamiętasz, Andrej? Graliśmy w hacele. Ale mój własny brat, posłałem własnego brata na rozstrzelanie, drogi Andreju!"

„Gorączka piotrowa, petersburgizm? Bolszewicy odgryzą komuś głowę. Co z tego? Nie ma bolszewika, nie ma żadnej Rosji! Dzikusy! Jest tylko... świat!"28.

Rosyjscy sekciarze przepowiedzieli, iż zamieć rewolucyjna powinna „zdzierać łuskę z wszystkiego, co martwe - śmierć z tego, co pół-żywe” na całej „Równinie Rosyjsko-Europejskiej”29. Ruch ten uczyniłby Rosję centrum Eurazji, jednocząc wszystkie żywotne siły narodowe na kontynencie, podobnie jak centrum pięciokąta w Nagim roku. Rosja stałaby się, w terminologii

\footnotetext{
${ }^{26}$ Pilnyak, 18.

${ }^{27}$ Oryg.: „Я утверждаю, что в России с низов глубоко - национальное здоровье, необходимое движение, ничего общего не имеющее с европейским синдикалистическим. В России анархический бунт во имя бесгосударственности, против всякого государства. Я утверждаю, что Россия должна была - и изживает лихорадку петровщины, петербурговщины, лихорадку идеи, теории, математического католицизма. Я утверждаю большевизм, разиновщину, и отрицаю коммунизм". Pilnyak, Sankt-Piter-Burkh, 17. Por. ang. tłum.: Pilnyak, The Tale of the Unextinguished Moon: And Other Stories, 110.

${ }^{28}$ Oryg: „«Помнишь, Андрей, мы играли в бабки. Но я своего брата послал расстрелять, милый Андрей!»«Петровщина Лихорадка, Санкт-питербурговщина? Большевик голову откусит, возьмет в рот и так: хак?! - Нет большевика, нет никакой России, - дикари! Есть - мир!»”. Pilnyak, Sankt-Piter-Burkh, 18.

${ }^{29}$ Pilnyak, The Tale of the Unextinguished Moon: And Other Stories, 106. Por. ang. tłum.: Pilnyak, The Tale of the Unextinguished Moon: And Other Stories, 111.
} 
Pilniaka, drugim Państwem Środka (vtoraia Imperiia Serediny) ${ }^{30}$, tak jak pierwszym Państwem Środka były $\mathrm{Chiny}^{31}$. Rolę państwa rosyjskiego jako miejsca spotkań rewolucjonistów-anarchistów różnych narodowości znamionuje podróż do Rosji chińskiego buntownika, Li Yana. Jak podaje historia, Li Yan urodził się w chłopskiej rodzinie, niedaleko miasta Dushikou, a jego ojciec, kiedy on sam był jeszcze dzieckiem, brał udział w powstaniu bokserów wywołanym przeciwko inwazji cudzoziemców, a następnie zginął w wiejskim starciu po wybuchu rewolucji Xinhai. Li Yan wkrótce opuścił dom i udał się do Pekinu, a następnie przez Władywostok do Rosji. Tam trafił do więzienia, uznany być może przez Rosyjski Rząd Tymczasowy za bolszewika. Uwięziony Li Yan śpiewa pieśń wojenną, którą słyszał jako dziecko, gdy jego ojciec śpiewał ją z innymi członkami stowarzyszenia „Pięści w imię sprawiedliwości i pokoju”, organizacji, która przewodziła powstaniu bokserów. Scena w więzieniu dopełnia samoidentyfikację Li Yana, łącząc jego aktualną bolszewicką tożsamość z dziecięcym wspomnieniem życia wśród wiejskich buntowników. Umieszczenie rewolucji chińskiej w kontekście powstań chłopskich potwierdza spojrzenie Pilniaka na rosyjską rewolucję. W rekonstrukcji paralelnych historii dwóch narodów, jaką tworzy pisarz, chińskie i rosyjskie bunty antyimperialistyczne są zakorzenione w poszczególnych tradycjach dotyczących oporu przeciwko obcym wpływom, ideom i praktykom.

Definiując rosyjską rewolucję jako świadomy wyraz stłumionej energii i kreatywności, zakłada się walkę przeciwko wszystkiemu, co obce w życiu narodowym, łącznie z identyfikacją z Europą, do której przyzwyczaiła się inteligencja. Taka mentalność musi zostać wydarta z rosyjskich dusz dzięki rewolucji, która jest ruchem oczyszczającym, podobnym do zamieci w Nagim roku zdzierającej inkrustacje z rosyjskiej ziemi. W opowiadaniu Bol'shoe serdtse (Wielkie serce, 1927) Pilniak wychwala narodową siłę oporu, jaką rdzenni Mongołowie przejawiają wobec europejskich kapitalistów. Wielkie serce pokazuje, że Pilniak usiłował przyjąć głos bolszewika, który opowiada się za zasiłkami dla wyzyskiwanego proletariatu trzeciego świata i świadomie dystansuje się od zeuropeizowanego i kapitalistycznego sposobu myślenia.

Wielkie serce opowiada historię trzech angielskich przedsiębiorców, którzy zamierzają negocjować z mongolskim wodzem w sprawie ekspansji ich fabryki oleju na Chiny. Zostają oni upokorzeni przez mongolskie plemię spiskujące przeciwko nim razem z ich mongolskim tłumaczem. Od samego początku powieści Pilniak stara się zerwać ze stereotypem eurocentrycznych Chin, przyjmując perspektywę narracyjną, która oddala się od „europejskich oczu” i „europejskiego ucha":

Dla Europejczyka na oko wszyscy Chińczycy mają tę samą twarz. W swoich rządowych koncesjach Europejczycy uważają za plagę, kiedy jeden Chińczyk zarobi około stu dayans i wraca do domu w Czifu, po tym jak sprzeda swoje miejsce pracy bratu bądź przyjacielowi za dwa dayans razem z paszportem. I tak nieeuropejskie oczy i nieeuropejskie ucho byłyby potrzebne, aby złapać tę krótką wymianę zdań przy płocie fabryki:

\footnotetext{
${ }^{30}$ Pilnyak, Sankt-Piter-Burkh, 7.

${ }^{31}$ Wyobrażenie Pilniaka na temat „drugiego Państwa Środka” kłóci się z jego wizją „Moskwy jako trzeciego Rzymu”, którą przedstawia w opowiadaniu Tret'ia stolitsa (Trzecia stolica, 1922). W tym świetle wybór takiego paradygmantu w Sankt-Piter-Burkhu pozwala Pilniakowi nie tylko zaprezentować jego eurazjanistyczny projekt, ale także odrzucić wszelkie związki z tradycją judeochrześcijańską.
} 


\author{
„Czy jesteś Mongołem?” \\ „Nie, jestem Chińczykiem. Chcę być z Rosją. A Ty jesteś Mongołem?” \\ „Tak, jestem. W waszym pociągu jedzie mongolski boy z Shin-Barga. Obaj jesteśmy z Shin-Barga, \\ z Kwot-ulang. Zajmę twoje miejsce"32.
}

\begin{abstract}
„Nieeuropejskie ucho" pozwala narratorowi zarejestrować rozmowę między chińskim pracownikiem a Mongołem, który chce kupić jego stanowisko. Narrator potrafi jednak pożyczyć "europejskie oczy”, aby ironicznie obserwować stereotypowy obraz Chin. Tuż po przywołanej wyżej rozmowie narrator opisuje miasto, w którym fabryka oleju sojowego przedstawiana jest z egzotycznym akcentem, łączącym piękno i brud, pociąg i wstręt, fascynację i strach a wszystko zawarte w ujęciu stóp Chinki „odkształconych w bucie piękna”33. Samo miasto porównane jest do „mrowiska” (muraveinik) ${ }^{34}$ - motyw kojarzony już przez Dostojewskiego w dziele Baal z kitaizmem, w którym stanowi symbol społeczeństwa zorganizowanego wokół powszechnego kultu materializmu. Pilniak pragnie uzyskać kontrast między zakorzenionym obrazem Chin będącym mieszanką egzotycznego chinoiserie i prymitywnego kitaizmu a realistycznym i obiektywnym portretowaniem robotników miejskich fabryk, mężczyzn, kobiet i dzieci, którzy walczą o przetrwanie w nieludzkich warunkach pracy:
\end{abstract}

Kobiety, staruszki i nastolatki, nagie, ze szmacianymi przepaskami na biodrach, stały w bębnach w dziale mielenia, gdzie kruszono ziarna na kaszę. Obracały się razem z bębnami, pośrodku nich, zamiatając śmieci i sortując ziarna. Kobiety na tym stanowisku - nieważne czy staruszki czy nastolatki - wymieniają się co trzy miesiące, gdyż po trzech miesiącach takiej pracy ludzie zwykli umieraćc ${ }^{35}$.

Szczegóły życia z fabryki oleju nie obchodzą „europejskich oczu”, które Pilniak wykorzystuje do opisania trzech Anglików współpracujących przy projekcie ekspansji przedsiębiorstwa. Każdy z tych dżentelmenów reprezentuje stereotypową osobowość i poglądy charakterystyczne dla kapitalistycznego i kolonialnego myślenia. Pan Gray to archetypiczny kapitalista zajęty powiększaniem zysków i majątku. Rozumie i szanuje tylko „teorię kapitału finansowego” oraz wierzy, iż jest ona kluczem do postępu ludzkości. W jego oczach chińscy robotnicy fabryki to jedynie narzędzia oraz liczby, które wymagają prowadzenia ksiąg rachunkowych, natomiast plemię mongolskie to grupa dzikusów, którą należy podbić. Pan Smith z kolei reprezentuje europejskiego, romantycznego poszukiwacza przygód, który jest zawsze gotowy do odkrywania nieznanych ziem, upajania się „burzą na morzu”, który ma słabość do „jakichś małych Japoneczek”

\footnotetext{
${ }^{32}$ Oryg: „На глаз европейца все китайцы однолицы; на концессиях европейцы считают бичом, когда один китаец наработает даян сто и уходит к себе в Чифу, продав место брату или соседу за два даяна, вместе с паспортом. Поэтому надо было иметь не-европейский глаз и не-европейское ухо, чтобы услышать у заводского забора короткий разговор. «Ты - монгол?» «- Нет, я китаец. Я хочу быть с Россией. А ты монгол?» «Да, я монгол. У вас в поезде едет монгол-бой, из Шин-Барги. Мы оба из Шин-Барги, из Кувотулана. Я поеду вместо тебя»". Pilnyak, Sobranie Sochinenii, vol. 6, 167. Por. tłum. ang.: Pilnyak, The Tale of the Unextinguished Moon: And Other Stories, 193.

${ }^{33}$ Pilnyak, The Tale of the Unextinguished Moon: And Other Stories, 193-194.

${ }^{34}$ Pilnyak, 194.

${ }^{35}$ Oryg: „В дробильном отделении, где дробятся бобы в крупу, в барабанах стоят женщины, или старухи, или подростки, голые, с тряпками на чреслах. Они вертятся вместе с барабаном, посредине барабана, подметая сор и сортируя бобы: на этой работе женщины, - старухи или подростки, безразлично, - меняются каждые три месяца, ибо через три месяца такой работы люди умирают". Pilnyak, Sobranie Sochinenii, vol. 6, 169.
} 
bądź „muzyki chińskich bębnów”36. Trzeci dżentelmen, „filozof w khaki”, jest ucieleśnieniem filisterskiego epikurejczyka, który oddaje się pogoni za dostatkiem i przyjemnością, niezainteresowany najmniejszym wysiłkiem łączącym się z aktywnością mentalną:

Trzeci mężczyzna, filozof w khaki, wstał niezdarnie ze swego fotela, nałożył okulary na czoło, i widoczne było, jak pieczołowicie ugniata to swoje khaki, siadając na każdym rodzaju krzesła.

$[\ldots]$

Trzeci, filozof w khaki, wrócił z wizyty w toalecie.

„Nie sądzicie panowie, że rozmawiacie tylko po to, żeby rozmawiać, podczas gdy mamy do wykonania bardziej znaczącą pracę? Na przykład, jest pora na whisky, a potem musimy zmierzyć się z zupełnie nudnym zadaniem obliczenia stawek towarów dla północnych i południowych oddziałów”37.

Pilniak wyraża swoją niechęć do kolonializmu i imperializmu w odmowie przyjęcia przez mongolskie plemię łapówki, którą Anglicy zaoferowali dla dobra własnego interesu. Pan Smith początkowo tak chętny, by czerpać przyjemność z wizyty, na którą zostali zaproszeni przez wodza, jest zamiast tego poruszony i zniesmaczony na widok głowy wbitej na bramę fortecy i jedzenia przyrządzonego ze zgniłych jaj. Wizyta kończy się w pośpiechu na skutek nieoczekiwanego zastraszenia: koń, podarowany przez wodza Anglikom, zostaje zastrzelony na oczach pana Greya trzymającego wodze. Cudzoziemcy spieszą do pociągu i szybko uciekają. Step przedstawiony w prozie Pilniaka stanowi „pustynię dla Europejczyka”, ale „ojczyznę dla Mongołów”, którzy są jedynymi odczuwającymi palące słońce jako łaskawe „wielkie serce”"38. Skuteczna obrona stepu przed kapitalistycznym wtargnięciem podsumowuje antykolonialne i antyeuropocentryczne rozważania autora.

Zdaje się, że zarówno Sankt-Piter-Burkh, jak i Wielkie serce przygotowały grunt pod wyprawę Pilniaka do Chin w 1926 roku, która stała się tematem jego na poły fabularyzowanego dziennika podróży. Kitajskij dniewnik (Dziennik chiński) opublikowany w 1927 roku (a także jako Kitaiskaja povest [Chińska opowieść] w 1928 roku) stanowił zapis wrażeń pisarza z pobytu w kilku chińskich miastach, w tym Szanghaju, Pekinie, Hankou, przeplatany fikcyjnym opisem działalności chińskich rewolucjonistów, życiem cudzoziemców w koncesjach, a także historią rosyjskiego towarzysza podróży - Kryłowa.

Pilniak przybył do Chin w czasie wielkiego zamieszania społecznego, kiedy watażkowie, rząd nacjonalistyczny i zagraniczne siły imperialne walczyły o władzę polityczną oraz zyski z przedsiębiorstw, kiedy partia komunistyczna przygotowywała się do kontrataku na partię nacjonalistyczną, która, choć początkowo współpracowała z tą pierwszą, zaczęła później przeprowadzać czystkę członków komunistycznych. W początkowych partiach swojego dziennika Pilniak wie-

\footnotetext{
${ }^{36}$ Pilnyak, The Tale of the Unextinguished Moon: And Other Stories, 200.

${ }^{37}$ Oryg.: „Третий, философ в хаки, вылезает из своего кресла, очки он ссовывает на лоб, - и видно, как его хаки старательно измято креслами и стульями, на которых он пересидел за век своего хаки. [...] Третий, философ в хаки, возвращается из уборной. «- Вам не кажется, джентльмэны, - говорит он - что вы разговариваете только для того, чтобы разговаривать, хотя у нас есть работы более существенные. Например, надо выпить сода-виски и после виски приступить к совершенно скучному подсчету тарифов с северных и южных веток [...]»". Pilnyak, Sobranie Sochinenii, vol. 6, 175-176. Por. tłum. ang.: Pilnyak, The Tale of the Unextinguished Moon: And Other Stories, 200-201.

${ }^{38}$ Pilnyak, The Tale of the Unextinguished Moon: And Other Stories, 218-220.
} 
lokrotnie przedstawia wstrząsający kontrast pomiędzy wyjątkowo złymi warunkami życia mas - zarówno robotników w miastach, jak i mieszkańców wsi - a sytuacją w miejskich koncesjach, gdzie cudzoziemcy cieszą się swymi „niematerialnymi, niezakłóconymi, nienaruszalnymi” przywilejami ${ }^{39}$. Aby lepiej naświetlić czytelnikom ten kontrast, Pilniak zacytował akapit lokalnej gazety z Szanghaju, w którym cudzoziemcy uważają za niedopuszczalne i niezwykle irytujące, że administracja w koncesjach nie zważa na Chińczyków, którzy pozwalają sobie wejść do lokalnych parków, jeszcze nie tak dawno oznaczonych jako „niedostępne dla psów i Chińczyków” ${ }^{40}$. Pilniak zapisuje także codzienne udręki, które musi przejść chiński rikszarz służący Anglikom w Hankou:

Anglik w korkowym hełmie, śnieżnobiałym garniturze, białych butach siedzi w rikszy, poganiając rikszarza tym swoim białym butem. Rikszarz toruje drogę przez masy ludzkie ochrypłym krzykiem. Tak to właśnie jest: w Pekinie, w Wuchang, w Hankou, w Sikhs - na skrzyżowaniach stoją Sikhowie-hindusi w szkarłatnych turbanach - brytyjska policja kolonialna. Sikhowie trzymają w rękach bambusowe kije i smagają nimi po udach każdego, każdego przejeżdżającego chińskiego rikszarza bądź kulisa. Tak właśnie jest wszędzie, gdzie są angielskie lub „międzynarodowe” koncesje. Nigdzie nie ma tyle policji jak w Chinach i nigdzie tak bardzo nie biją i tłuką jak w Chinach! ${ }^{41}$

Pilniak nigdy nie waha się przed wyszydzaniem porządku, komfortu i „cywilizowanej nowoczesności” życia emigrantów w chińskich koncesjach. Naśmiewa się także z „humanitarnej troski” oraz „moralnej wyższości” europejskich i amerykańskich rezydentów. Opowiada na przykład historię o tym, jak Amerykanin, chcąc rozdzielić dwóch Chińczyków kłócących się na ulicy, „dla dobra porządku” $\mathrm{i}, z$ humanitarnego impulsu”"2, pobił i skopał jednego z nich prawie na śmierć, po czym odjechał samochodem $z$ dwoma innymi cudzoziemcami. Za pomocą tej sceny Pilniak pokazuje także apatię Chińczyków, którzy nawykli już do niekończących się bijatyk, utarczek i udręk, pozbawiając się przy tym ludzkiej wrażliwości oraz godności:

Wydawało mi się, że Amerykanin zabił Chińczyka. [...] Ale Chińczyk podniósł się, a tamten ponownie - z westchnieniem ulgi - kopnął go w plecy. Chińczyk uciekł od Amerykanina, tak jak uciekają zbite psy. Około dwustu gapiów stało wokół... ${ }^{43}$

Jedyne światło w tej ciemności Pilniak dostrzegał w pojedynczych buntownikach, którzy powstają przeciwko wszystkim: przeciwko watażkom, kolonizatorom, straży miejskiej,

\footnotetext{
${ }^{39}$ Boris Pilnyak, Chinese Stories and Other Tales, tłum. Vera Reck i Michael Green (Norman: University of Oklahoma Press, 1988), 24.

${ }^{40}$ Pilnyak, s. 28.

${ }^{41}$ Oryg.: „Англичанин в пробковом шлеме, в белоснежном костюме, в белых туфлях - сидит в рикше, подгоняет ломпацо белой своей туфлей в спину, - ломпацо расталкивает человеческую толпу охриплым криком: это и в Пекине, и в Ханькоу, и в Учане - на перекрестках стоят «сикхи» - индусы в малиновых чалмах - английская колониальная полиция, - у сикхов в руках бамбуковые палки - и каждого, каждого китайца, пробегающего мимо, кули или ломпацо, бьют сикхи этими бамбуками по ляжкам: это везде, где есть английские или «международные» концессии. - Нигде нет столько полиции, как в Китае, - и нигде так много не бьют и не дерутся, как в Китаe!”. Pilnyak, Sobranie Sochinenii, vol. 7, 188. Por. ang. tłum.: Pilnyak, Chinese Stories and Other Tales, 27.

${ }^{42}$ Pilnyak, Chinese Stories and Other Tales, s. 83.

${ }^{43}$ Oryg.: „Мне показалось, что американец убил китайца. [...] Но китаец поднялся, - тогда американец еще раз ударил - облегчено вздохнув - ногою по спине. Китаец побежал от американца - так, как бегают битые собаки. Кругом стояло человек двести зрителей - -". Pilnyak, Sobranie Sochinenii, vol. 7, 251. Por. tłum. ang.: Pilnyak, Chinese Stories and Other Tales, 83.
} 
przedsiębiorcom, kompradorom, „tym, o których wolność walczy Ameryka”, jednym słowem przeciw „niedorzecznej rzeczywistości”. Pilniak rysuje historię takiego buntownika, Liu Hua, który urodził się jako chłopskie dziecko, a został jednym z przywódców Ruchu 30 Maja w Szanghaju. Opowieść Pilniaka to połączenie reportażu dziennikarskiego i pisarstwa fikcyjnego z dodatkiem wielu zmyślonych szczegółów. Co ciekawe, opowiadanie to splata się z fikcyjną historią panny Brighton, Amerykanki, członkini grupy misyjnej Siccawei, która przybyła do Chin z San Francisco, by „w duchu chrześcijańskim nauczać dzikich Chińczyków” 44 . Losy dziewczyny skrzyżowały się z losami Liu Hua, pracującego jako bibliotekarz, gdy ta pożyczyła od niego książki. Jednakże, kiedy Liu Hua organizował związek robotniczy i chował się przed prześladowaniami policjantów, panna Brighton odbywała egzotyczną wycieczkę w Pekinie ze swoim amerykańskim znajomym. Kiedy Liu Hua został stracony, panna Brighton brała właśnie ślub z sekretarzem brytyjskiego konsulatu, człowiekiem reprezentującym Brytyjczyków w sądzie miejskim, który „siłą rzeczy przyłożył rękę do sprawy Liu Hua”, bez żadnej świadomości, że była „kochana przez półnagiego bibliotekarza, który nie mógł podążyć za nią do Jestfield Parku”, ponieważ „psom i Chińczykom wstęp wzbroniony”"

Pilniak jest jednak świadomy, tak jak w przypadku „angielskich dżentelmenów” w Wielkim sercu, że tworzy stereotypowy obraz człowieka Zachodu, za którym idzie stereotypowa wizja Wschodu. Podobnie jak przedsiębiorcy w Wielkim sercu, panna Brighton także pozbawiona jest psychologicznej głębi i złożonego charakteru. Zamiast tego naszkicowana jest w taki sposób, by przedstawiać osobę, która, według samych słów autora, miała „subiektywnie patrząc... rację zawsze i wszędzie", ale nie wtedy, gdy spojrzało się na sprawę obiektywnie ${ }^{46}$. Wymyślając pannę Brighton, Pilniak nie wyśmiewa hipokryzji „oświecającego projektu” Zachodu, ale pragnie zwrócić uwagę na niemałą przepaść między dobrymi intencjami a skutecznym działaniem, a także na ogromne trudności we współodczuwaniu i zaangażowaniu cudzoziemca, który nie jest gotowy zmierzyć się z nieprzewidywalną rzeczywistością i zostać przez nią odrzuconym; jak pisze autor:

...potem wszystko miało być takie, jak wyobrażała sobie po drodze, jak wytworzyła sobie z listów przyjaciela i ze zdjęć - ponieważ jej życie było wzniesione na tradycjach, na surowych przepisach; Amerykanie i Anglicy nie mają pojęcia o znaczeniu słowa „za granicą”, żyjąc jak Amerykanie nawet w Chinach i znając swoją przyszłość z trzyletnim wyprzedzeniem - co do tygodnia - i bez błędów! ${ }^{47}$

Chociaż obecne w Chinach napięcie między Wschodem a Zachodem przykuło uwagę pisarza, w wielu miejscach dziennika Pilniak podejmuje inny temat: porównanie Rosji i Chin. Z jednej strony autor często wyraża brak zrozumienia dla Chin, gdy idzie o kwestie jedzenie, zapa-

\footnotetext{
${ }^{44}$ Pilnyak, Chinese Stories and Other Tales, 60. Grupa misjonarzy Siccawei była wspólnotą jezuicką, która miała swoją siedzibę w dzisiejszym dystrykcie Xu Jiahui w Szanghaju.

${ }^{45}$ Pilnyak, 73-74.

${ }^{46}$ Pilnyak, 61.

${ }^{47}$ Oryg: „...все впоследствии так и было, как представляла она себе в пути, как создала она по письмам подруги и по фотографиям, - потому что жизнь ее построена была традициями, строгими курантами регламентов, когда американцы и англичане не имеют понятия «заграница», проживая даже в Китае поамерикански, - и когда они могут - за три года вперед с точностью до недели знать свое будущее - и не ошибаться!". Pilnyak, Sobranie Sochinenii, vol. 7, 226. Por. tłum. ang.: Pilnyak, Chinese Stories and Other Tales, 61.
} 
chu, przyrody itd. Z drugiej strony czuje, że ze wszystkich krajów, które odwiedził, to „Chiny najbardziej przypominają Rosję"48. Jak twierdzi, to właśnie tam nieustannie „natykał się na Rosję" i „nie jest żadnym przypadkiem, że zarówno Chiny, jak i Rosja zostały podbite przez Mongołów"49. W jednym fragmencie Pilniak opisuje, jak Pekin przypomina Moskwę z 1918 roku: żołnierze tłoczą się we wszystkich pałacach i świątyniach, „działobitnie, patrole pilnują skrzyżowań", a po ziemi walają się łupinki od pestek arbuza ${ }^{50}$. W innym akapicie opisuje poranek w Hankaou, który przywołał wspomnienie dzieciństwa w Saratowie:

...Obudziłem się dziś z najbardziej niesamowitym wrażeniem dzieciństwa, mojego dzieciństwa w Saratowie, w domu mojej babci Katarzyny Iwanownej, wśród odgłosów nadbrzeża, zgiełku pieśni Dubinuszki. Nie wiem, czy pożyczyli tę piosenkę od nas czy my od nich, ale wiem, że melodia i rytm tu w Hankowie, jak wszędzie w Chinach, jest taka sama jak w Saratowie i wszędzie nad Wołgą. [...] A rano, uwolniony od koszmaru spania pod moskitierą, poszedłem na nadbrzeże, by wędrować po moim dzieciństwie, gdyż obraz był, o dziwo, dokładnie taki sam: ci sami burłacy w różnych strojach, ci sami nadzorcy, mężczyźni noszący na plecach (niezrozumiałe, dlaczego nie pękają im grzbiety) worki i bele $[\ldots]^{51}$.

W akapicie zawierającym luźne refleksje Pilniak próbuje wyjaśnić pokrewieństwo między Rosją a Chinami, zwracając uwagę na nowoczesny rozwój, który pojawia się w obu państwach. Jak zaznacza Pilniak, zarówno w Rosji, jak i w Chinach masy konfrontują się z inteligencją. Tradycja, nasycona rytuałami, które dodawały jej powagi, dobrze zachowała się w rosyjskich i chińskich warstwach chłopskich. W obu nacjach inteligencja jawi się jako nieposiadająca własnej twarzy: wszystkie idee są zapożyczone z „kultury europejskiej”, która „niszczy model narodowy, usuwając jego charakterystyczne cechy jako zbyt czcze i lokalne"52. Jednak to właśnie zjawisko destrukcji, które osłabiło „filary” kultur narodowych, umożliwiło rozwój „nowej, światowej kultury” reprezentowanej przed takich bohaterów jak Liu Hua ${ }^{53}$. „Kultura światowa" - kulturowa buntu mas, walki o ludzką sprawiedliwość i dobrobyt - zdążyła zapuścić korzenie w Rosji, a także zakwitła w Chinach. Oba państwa stanowiłyby strony tworu „kultury ponadnarodowej", kultury, która kultywuje nową formę społecznej organizacji opartej na nowych relacjach międzyludzkich ${ }^{54}$.

To porównanie nowoczesnej historii Rosji i Chin, która uwypukla ich wspólną, dialektyczną naturę, podsumowuje obserwacje Pilniaka. Od „Kitaj-gorodu” w Nagim roku do państwa

${ }^{48}$ Pilnyak, Chinese Stories and Other Tales, 40.

${ }^{49}$ Pilnyak, 40-41.

${ }^{50}$ Pilnyak, 24.

${ }^{51}$ Oryg.: „...Я проснулся сегодня в удивительнейшем чувстве детства, моего детства в Саратове, в доме бабки Катерины Ивановны, в шуме набережной, в гуле дубинушки. Не знаю, кто у кого взял дубинушку, эту портовую дубинушку, - но знаю, что мотив и ритм ее здесь в Ханькоу, как везде в Китае, таков же, как в Саратове, как везде на Волге. [...] И утром, освободившись от кошмара сна в москитнике, я пошел на набережную - бродить по моему детству, ибо картина одна и та же, разительно, - такие же разноплеменно одетые бурлаки, такие же надсмотрщики, так же на спинах (непонятно, почему не ломаются хребты) тащат люди мешки и тюки". Pilnyak, Sobranie Sochinenii, vol. 7, 183. Por. tłum. ang.: Pilnyak, Chinese Stories and Other Tales, 22-23.

${ }^{52}$ Pilnyak, Chinese Stories and Other Tales, 58.

${ }^{53}$ Pilnyak, 59.

${ }^{54}$ Pilnyak. 
chińskiego czasów niepokoju w Dzienniku koncepcja Chin w perspektywie pisarza wyewoluowała z mitologizowanego miejsca, które ucieleśniało azjatycką stronę Rosji i projekt eurazjatycki, do samego centrum konfliktów, gdzie rozgrywały się dramaty kolonialnych ambicji i narodowych aspiracji. Chiny, które przedstawia Pilniak, są osadzone w różnych kontekstach historycznych, przechodząc od na poły fikcyjnego „Niebiańskiego Imperium”, które odzwierciedla historię Rosji, do państwa w kryzysie, który przypomni Rosjanom ich niedawną przeszłość. Ostatnie fragmenty prozy Pilniaka poświęcone kwestii chińskiej ukazują przesunięcie uwagi i zmianę perspektywy, gdy idzie o spojrzenie na Chiny lat 20. Dla pisarzy, takich jak Siergiej Trietiakow (1892-1937), Wsiewołod Iwanow (1895-1963) i Nikołaj Kostarev (1893-1939), „Chiny” nie są już uosobieniem tych systemów wartości, przekonań, modeli życia, które różniły je zarówno od Europy, jak i od post-Piotrowej Rosji. Raczej zaczęły funkcjonować jako społeczeństwo, które podążyło śladami Związku Radzieckiego i stało się „echem” Rosji Sowieckiej ${ }^{55}$. Zmiana wzorca literackiego korespondowała z ideologicznym przesunięciem i zmianą socjopolityczną w Związku Radzieckim w latach 20. XX wieku. Przez przedstawienie Chin, które buntowały się przeciwko własnej tradycji, rosyjscy pisarze, tacy jak Pilniak, nie tylko zaktualizowali obraz tego państwa dla rosyjskich czytelników, ale także zanalizowali je jako poligon socjopolitycznej transformacji, która pomaga oświetlić uniwersalne wartości i wpływ, jaki na świat mogłaby mieć sowiecka ideologia.

\section{Przełożyła Izabela Sobczak}

\footnotetext{
${ }^{55} \mathrm{~W}$ ostatnich latach pojawiło się kilka opracowań dotyczących sposobu obrazowania Chin we wczesnej sowieckiej literaturze. Na temat kulturowo-politycznej analizy przedstawień Chin w rosyjskiej literaturze lat 20. i 30. XX wieku zob. Edward Tyerman, „The Search for an Internationalist Aesthetics: Soviet Images of China, 19201935” (praca doktorska, Columbia University, 2014). Aby poznać transnarodowy wpływ teatralnej reprezentacji Chin Siergieja Trietriakowa w jego sztuce Rychi, Kitai! (Zaryczcie, Chiny!, 1926), zob. Mark Gamsa, „Sergei Tret'iakov's Roar, China! between Moscow and China", Itinerario 36, nr 2 (2012): 91-108. Na temat Chińskiej Armii Czerwonej w powieści Wsewołoda Iwanowa Armoured Train 14-69 (Bronepoezd No. 14-69, 1922) zob. Roy Chan, „Broken Tongues: Race, Sacrifice, and Geopolitics in the Far East in Vsevolod Ivanov's Bronepoezd No. 14-69", Sibirica 10, nr 3 (2011): 29-54.
} 


\section{Bibliografia}

Abdurazakova, Elena. „Tema Vostoka v tvorchestve Borisa Pil'niaka”. Rozprawa doktorska. Far Eastern Federal University, 2005.

Bassin, Mark. Glebov, Sergey. Laruelle, Marlene. „What Was Eurasianism and Who Made It?". W Between Europe and Asia: The Origins, Theories, and Legacies of Russian Eurasianism, 1-12. Zredagowane przez Mark Bassin, Sergey Glebov i Marlene Laruelle. Pittsburg: University of Pittsburg Press, 2015.

Browning, Gary. Boris Pilniak: Scythian at a Typewriter. Ann Arbor: Ardis Publishers, 1985

Damerau, Reinhard. Boris Pil'njaks Geschichtsund Menschenbild: Biographische und thematische Untersuchungen. Giessen: Wilhelm Schmitz, 1976.

Doran, Sabine. The Culture of Yellow or the Visual Politics of Late Modernity. New York: Bloomsbury, 2013.

Kriuchkov, Vladimir. „O «prazdnoi mozgovoi igre» V "Sankt-Piter-Burkhe” B. A. Pil'niaka”. Voprosy literatury 2 (2005): 66-110.

Liubomova, M.I. „O Peterburgskikh povestiakh Borisa Pilnyaka". W Boris Pilnyak, Opyt sevodniashnevo prochteniia, 55-62. Moscow: Nasledie, 1995.

Maguire, Robert. Red Virgin Soil: Soviet Literature in the 1920's. Evanston: Northwestern University Press, 2000.

Moraniak-Bamburian, Nirman. „B.A. Pilnyak $\mathrm{i}$ «Peterburgskii tekst»". W B.A. Pilnyak. Issledovanija i materialy, mezhvuzovskii sbornik nauzhnykh trudov 1. Zredagowane przez Aleksandr Auer, 36-46. Kolomna: Izd-vo. KGPI, 2001.
Pilniak, Boris. Chinese Stories and Other Tales. Przetłumaczone przez Vera Reck and Michael Green. Norman: University of Oklahoma Press, 1988.

——. Mashiny i volki. Munich: W. Fink, 1925.

Maszyny i wilki. Przełożyła i posłowiem opatrzyła Janina Dziarnowska. Warszawa: Czytelnik 1984.

Sankt-Piter-Burkh. Letchworth: Prideaux Press, 1979.

Sobranie Sochinenii. Moscow: Gos. izdvo., 1929.

Stat’i 1922-1929. Moscow: Sovetskii pisatel', 1991.

Pilnyak, Boris. Nagi rok. Przetłumaczone przez Janina Dziarnowska. Wstępem opatrzyła Ewa Korpała-Kirszak. Warszawa: Państwowy Instytut Wydawniczy, 1987.

The Tale of the Unextinguished Moon and Other Stories. Przetłumaczone przez Beatrice Scott. New York: Washington Square Press, 1967.

Prokhorov, Aleksandr, red. Bol'shaia sovetskaia entsiklopediia. Moscow: Sov. entsiklopediia, 1973.

Solzhenitsyn, Aleksandr. „ "Golyi god» Borisa Pilnyaka". Novyi mir 1 (1997): 195. 


\title{
SŁOWA KLUCZOWE:
}

\author{
Sankt-Piter-Burkh
}

Kitajskijdniewnik

\section{E U R A Z J A N I Z M}

\begin{abstract}
AbSTRAKT:
Artykuł omawia sposób przedstawiania i opisywania Chin w dziełach Borisa Pilniaka. Autor stawia tezę, iż twórczość fikcyjna i dzienniki podróżne Pilniaka reprezentują dwa podejścia w literackiej reprezentacji Chin: wyobrażone [imaginary] i dokumentarne [documentary]. Elementem łączącym owe podejścia jest fundamentalna dla pisarza wizja eurazjatycka, którą z jednej strony można postrzegać jako dziedzictwo uniwersalistycznej postawy rosyjskiej tradycji modernistycznej, a z drugiej jako odpowiedź na kryzys tożsamości narodowej, który wyrasta z ówczesnych realiów geopolitycznych. Wyobrażenia Pilniaka na temat Chin miały charakter produktu ubocznego wyobraźni poetyckiej w dziełach napisanych przed 1922 rokiem. Tam kontynuowany był palimpsestowy proces wpisywania mitu chińskiego w rosyjskie środowisko literackie, co przekładało się na utrwalenie pojęciowej internalizacji „Chin” w kształtującej się po swojemu Rosji. Przykładem jest obraz „Kitaj-gorodu” w powieści Nagi rok, który generował różne symboliczne znaczenia Chin. Od roku 1922 wariacje narracyjnej scenerii w prozie Pilniaka odzwierciedlały wpływ ówczesnych wydarzeń na obsesyjne myśli autora dotyczące historycznego związku Rosji i Azji. Wielkie znaczenie dla Pilniaka miała jego wyprawa do Chin w 1926 roku, której rezultatem jest Kitajskij dniewnik (Dziennik chiński). Państwo chińskie staje się tam punktem odniesienia rosyjskiej autorefleksji, socjopolitycznych i ideologicznych wahań. Łącząc wyobrażenie historii z komentarzem na temat rzeczywistości, Pilniak, w różnych sposobach przedstawiania Chin, pragnął zobrazować zmieniającą się tożsamość Rosji, zarówno z jej mitologizowanej przeszłości, jak z i uwydatnionej teraźniejszości.
\end{abstract}


praktyki | Hui Zhang, Obraz Chin w eurazjatyckim projekcie Borisa Pilniaka...

\section{Nagi rok}

\section{PILNIAK}

\section{Chiny}

\section{NOTA O AUTORZE:}

Hui Zhang (ur. 1988) - doktoryzował się na Wydziale Języków i Literatury Słowiańskiej Uniwersytetu Northwestern. Obecnie pracuje na Szanghajskim Uniwersytecie Studiów Międzynarodowych. Zajmuje się rosyjskim modernizmem, rosyjskim orientalizmem, rosyjską fantastyką. 